America's Congress 

$\begin{array}{lllllllllllll}\text { D } & \text { A } & \text { V } & \text { I } & \text { D } & \text { R. } & \text { M } & \text { A } & \text { Y } & \text { H } & \text { E } & \text { W }\end{array}$

\section{America's Congress}

Actions in the Public Sphere, James Madison Through Newt Gingrich 


\section{To my wife, Judith}

Copyright (C) 2000 by Yale University. All rights reserved. This book may not be reproduced, in whole or in part, including illustrations, in any form (beyond that copying permitted by Sections 107 and 108 of the U.S.

Copyright Law and except by reviewers for the public press), without written permission from the publishers.

Set in Scala type by Tseng Information Systems.

Printed in the United States of America by/Vail-Ballou Press, Binghamton, New York.

Library of Congress Cataloging-in-Publication Data

Mayhew, David R.

America's Congress : actions in the public sphere, James Madison through Newt Gingrich / David R. Mayhew.

p. $\quad \mathrm{cm}$.

Includes bibliographical references and index.

IS B N 0-300-08049-2 (cloth : alk. paper)

I. United States. Congress - History. 2. Legislators-United StatesHistory. I. Title.

JKIO2I .M39 2000

328.73'09-dc2I

$99-086055$

A catalogue record for this book is available from the British Library. The paper in this book meets the guidelines for permanence and durability of the Committee on Production Guidelines for Book Longevity of the Council on Library Resources.

I0 $9 \begin{array}{lllllllll} & 8 & 7 & 6 & 5 & 4 & 3 & 2 & \text { I }\end{array}$ 